\title{
Physiologic Specialization of Puccinia triticina on Wheat in the United States in 2011
}

\author{
J. A. Kolmer and M. E. Hughes, USDA-ARS Cereal Disease Laboratory, St. Paul, MN 55108
}

\begin{abstract}
Kolmer, J. A., and Hughes, M. E. 2013. Physiologic specialization of Puccinia triticina on wheat in the United States in 2011. Plant Dis. 97:11031108 .

Collections of Puccinia triticina were obtained from rust-infected leaves provided by cooperators throughout the United States and from wheat fields and breeding plots by USDA-ARS personnel and cooperators in the Great Plains, Ohio River Valley, southeastern states, Oregon, and Washington State in order to determine the virulence of the wheat leaf rust population in 2011. Single uredinial isolates (440 total) were derived from the collections and tested for virulence phenotype on 18 lines of Thatcher wheat and a winter wheat line that are near-isogenic for 19 leaf rust resistance genes. In 2011, 87 virulence phenotypes were described in the United States. Virulence phenotypes TBBGJ,

MLDSD, and TCRKG were the three most common phenotypes. Phenotype TBBGJ is virulent to $L r 39 / 41$ and was widely distributed throughout the hard red winter wheat region of the Great Plains. Phenotype MLDSD is virulent to $\operatorname{Lr} 17$ and Lr39/41 and was widely distributed throughout the United States. Phenotype TCRKG is virulent to $L r 11, L r 18$, and $L r 26$ and was found mostly in the soft red winter wheat region in the eastern United States. Isolates with virulence to Lr39/41 and avirulence to $\operatorname{Lr} 9$ were prevalent in the Great Plains region for the first time. Virulence to $L r 21$ was present in five virulence phenotypes mostly from the spring wheat region of the northern Great Plains.
\end{abstract}

Leaf rust, caused by Puccinia triticina Eriks., is a common disease of wheat (Triticum aestivum L.) in the United States and worldwide (19). In the United States, P. triticina can overwinter in winter wheat that is infected in the fall by urediniospores from the previous summer's crop or volunteer wheat. Leaf rust can overwinter regularly on susceptible wheat cultivars throughout the southern Great Plains from Texas to Nebraska (2) and occasionally as far north as southern Minnesota and South Dakota. Leaf rust also overwinters regularly in the Gulf Coast states and in the coastal plain from Georgia through Virginia (7). As the winter wheat crop develops and matures throughout the Great Plains, leaf rust infections also spread and increase. Leaf rust severity reaches maximum levels on winter wheat starting in April in Texas and culminating in June and July in Nebraska and South Dakota (2). Leaf rust infections are usually first observed on spring-planted wheat in Minnesota, South Dakota, and North Dakota by mid-June. Leaf rust infections in the north-central spring wheat region usually reach maximal levels by the end of July. In the soft red wheat region of the southeastern states, leaf rust severity usually reaches maximal levels starting in April in Georgia and ending in May in North Carolina and Virginia (7). In the soft red wheat area of southern Illinois, Indiana, and Ohio, leaf rust infections are highest by the middle of June.

Yield losses due to leaf rust have been heaviest in the winter wheat region from Pennsylvania to Kansas and Oklahoma (18). Years with the heaviest yield losses often had temperature and moisture conditions that also favored wheat yields. In the last 20 years, leaf rust has caused an average loss of nearly $4 \%$ in Kansas,

Corresponding author: J. A. Kolmer, E-mail: Jim.Kolmer@ars.usda.gov Accepted for publication 8 February 2013.

http://dx.doi.org/10.1094/PDIS-11-12-1068-SR

This article is in the public domain and not copyrightable. It may be freely reprinted with customary crediting of the source. The American Phytopathological Society, 2013. although annual losses can be much higher as in 2007 (1) when leaf rust caused a $14 \%$ loss. In epidemic years, losses due to leaf rust in plots of spring wheat cultivars ranged from 5 to $40 \%$ depending on the resistance of the cultivar (J. Kolmer, unpublished data).

In the United States, the different market classes of wheat have different genes for leaf rust resistance. The hard red winter wheat cultivars grown from Texas to South Dakota have seedling genes Lr1, Lr3, Lr10, Lr11, Lr14a, Lr16, Lr17, Lr24, Lr26, and Lr39/41. The soft red winter wheat cultivars grown in the southern, eastern, and Ohio Valley regions have genes $\operatorname{Lr} 1, \operatorname{Lr} 2 a, \operatorname{Lr} 3, \operatorname{Lr} 9, \operatorname{Lr} 10$, Lr11, Lr14a, Lr18, Lr24, and Lr26 (8). The hard red spring wheat cultivars grown in Minnesota, North Dakota, and South Dakota have genes $L r 1, L r 2 a, L r 10, L r 16, L r 21$, and $L r 23$ (16,17). These genes condition resistance to specific races or virulence phenotypes of $P$. triticina. Phenotypes with virulence to these genes have almost inevitably emerged within a few years after the genes were used in wheat cultivars. As a result, different virulence phenotypes are often found in the three different wheat regions.

The USDA-ARS Cereal Disease Laboratory has conducted virulence surveys of the wheat leaf rust fungus since 1978 (12) to detect new virulence phenotypes and to monitor shifts of virulence phenotypes in the major wheat growing regions of the United States. Earlier surveys of leaf rust virulence that started in 1926 were conducted by the USDA-ARS in Kansas (4) and Indiana (13). Similar surveys have been done in Canada since $1931(3,14)$. In the United States (10) and Canada (6), data from leaf rust surveys have been used to characterize virulence dynamics and phenotypic diversity within and between wheat growing regions. The objectives of this study were to characterize the virulence of $P$. triticina populations in the United States in 2011 with the North American wheat leaf rust differentials and to compare these results with those of previous surveys.

\section{Materials and Methods}

Leaf rust occurrence and isolate collections. In 2011, USDAARS personnel and cooperators in the United States made a total of 256 uredinial collections of leaf rust from wheat plots and fields 


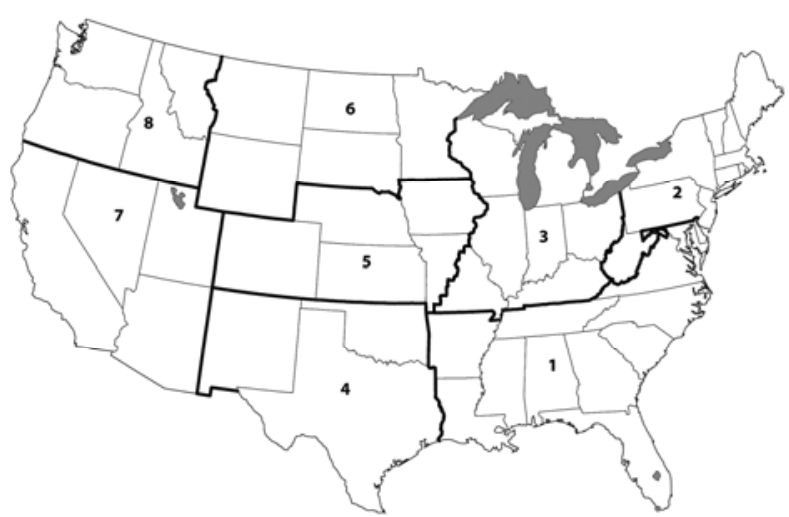

Fig. 1. Agroecological areas for Puccinia triticina in the United States. Area 1, mainly southern-adapted soft red winter wheat; Areas 2 and 3, mostly northernadapted soft red and soft white winter wheat; Area 4, mixed wheat types but primarily hard red winter; Area 5 , hard red winter wheat; Area 6 , mixed wheat types but primarily hard red spring and durum; Area 7, spring wheat planted in late fall; and Area 8, mixed wheat types but primarily soft white winter. in surveys of the Great Plains, Ohio River Valley, and southeastern states. Field surveys of wheat were made by USDA-ARS personnel in southern and central Texas (late March); northern Texas and south-central Oklahoma (late April); Oklahoma, Kansas, and western Missouri (late May); north-central Kansas, Nebraska, western Iowa, South Dakota, and southern Minnesota (mid-June); and Minnesota, North Dakota, South Dakota, and Wisconsin (early July and again in late July). Additional collections were made in wheat breeding nurseries, trap plots, and demonstration plots along the route. Nurseries typically contain a wide array of regional cultivars and breeding lines with various combinations of leaf rust resistance genes. Trap plots usually contain older, leaf rust susceptible wheat cultivars that are no longer prominent in commercial production. A collection consisted of one to several leaves with $P$. triticina uredinia from a single plant or cultivar. The leaves were air-dried at room temperature and stored at $4{ }^{\circ} \mathrm{C}$ until spores were collected for inoculation and increase. Collections from inoculated nurseries were not included in the study.

Identification of virulence phenotypes. Urediniospores from each collection were used to inoculate 7-day-old seedlings of the

Table 1. Number and frequency (\%) of virulence phenotypes of Puccinia triticina in the United States in 2011 identified by virulence to $19^{\mathrm{a}}$ lines of wheat with single genes for leaf rust resistance

\begin{tabular}{|c|c|c|c|c|c|c|c|c|c|c|c|c|c|c|c|}
\hline \multirow[b]{2}{*}{ Phenotype } & \multirow[b]{2}{*}{ Virulence } & \multicolumn{2}{|c|}{ Area $1^{b}$} & \multicolumn{2}{|c|}{ Area $2^{c}$} & \multicolumn{2}{|c|}{ Area $3^{d}$} & \multicolumn{2}{|c|}{ Area $4^{\mathrm{e}}$} & \multicolumn{2}{|c|}{ Area $5^{\mathrm{f}}$} & \multicolumn{2}{|c|}{ Area $6^{\mathrm{g}}$} & \multicolumn{2}{|c|}{ Total } \\
\hline & & $\#$ & $\%$ & $\#$ & $\%$ & $\#$ & $\%$ & $\#$ & $\%$ & $\#$ & $\%$ & $\#$ & $\%$ & $\#$ & $\%$ \\
\hline BBBDG & $14 a, 28$ & 1 & 1.1 & 0 & 0 & 0 & 0 & 0 & 0 & 3 & 3.8 & 2 & 1.5 & 6 & 1.4 \\
\hline MBBJG & $1,3,10,14 a, 28$ & 0 & 0 & 0 & 0 & 1 & 2.5 & 0 & 0 & 0 & 0 & 1 & 0.7 & 2 & 0.5 \\
\hline MBDSD & $1,3,17, \mathrm{~B}, 10,14 \mathrm{a}, 39 / 41$ & 1 & 1.1 & 0 & 0 & 1 & 2.5 & 1 & 1.4 & 3 & 3.8 & 2 & 1.5 & 8 & 1.8 \\
\hline MBJJG & $1,3,11,17,10,14 a, 28$ & 0 & 0 & 0 & 0 & 0 & 0 & 0 & 0 & 1 & 1.3 & 0 & 0 & 1 & 0.2 \\
\hline MBPNB & $1,3,3 \mathrm{ka}, 17,30, \mathrm{~B}, 14 \mathrm{a}$ & 0 & 0 & 0 & 0 & 1 & 2.5 & 0 & 0 & 0 & 0 & 0 & 0 & 1 & 0.2 \\
\hline MBPSB & $1,3,3 \mathrm{ka}, 17,30, \mathrm{~B}, 10,14 \mathrm{a}$ & 0 & 0 & 0 & 0 & 0 & 0 & 0 & 0 & 2 & 2.6 & 1 & 0.7 & 3 & 0.7 \\
\hline MBTNB & $1,3,3 \mathrm{ka}, 11,17,30, \mathrm{~B}, 14 \mathrm{a}$ & 5 & 5.4 & 1 & 4.8 & 4 & 10 & 0 & 0 & 0 & 0 & 5 & 3.7 & 15 & 3.4 \\
\hline MCDSB & $1,3,26,17, \mathrm{~B}, 10,14 \mathrm{a}$ & 0 & 0 & 0 & 0 & 2 & 5 & 0 & 0 & 1 & 1.3 & 2 & 1.5 & 5 & 1.1 \\
\hline MCDSD & $1,3,26,17, \mathrm{~B}, 10,14 \mathrm{a}, 39 / 41$ & 0 & 0 & 0 & 0 & 0 & 0 & 1 & 1.4 & 0 & 0 & 0 & 0 & 1 & 0.2 \\
\hline MCGJG & $1,3,26,11,10,14 a, 28$ & 0 & 0 & 3 & 14.3 & 0 & 0 & 0 & 0 & 0 & 0 & 0 & 0 & 3 & 0.7 \\
\hline MCJSB & $1,3,26,11,17, \mathrm{~B}, 10,14 \mathrm{a}$ & 0 & 0 & 0 & 0 & 2 & 5 & 0 & 0 & 0 & 0 & 0 & 0 & 2 & 0.5 \\
\hline MCLRG & $1,3,26,3 \mathrm{ka}, \mathrm{B}, 10,18,28$ & 0 & 0 & 1 & 4.8 & 0 & 0 & 0 & 0 & 0 & 0 & 0 & 0 & 1 & 0.2 \\
\hline MCPSB & $1,3,26,3 \mathrm{ka}, 17,30, \mathrm{~B}, 10,14 \mathrm{a}$ & 0 & 0 & 0 & 0 & 0 & 0 & 0 & 0 & 0 & 0 & 1 & 0.7 & 1 & 0.2 \\
\hline MCPSD & $1,3,26,3 \mathrm{ka}, 17,30, \mathrm{~B}, 10,14 \mathrm{a}, 39 / 41$ & 0 & 0 & 0 & 0 & 0 & 0 & 0 & 0 & 2 & 2.6 & 0 & 0 & 2 & 0.5 \\
\hline МСРТВ & $1,3,26,3 \mathrm{ka}, 17,30, \mathrm{~B}, 10,14 \mathrm{a}, 18$ & 0 & 0 & 0 & 0 & 0 & 0 & 0 & 0 & 0 & 0 & 1 & 0.7 & 1 & 0.2 \\
\hline MCRGG & $1,3,26,3 \mathrm{ka}, 11,30,10,28$ & 0 & 0 & 1 & 4.8 & 0 & 0 & 0 & 0 & 0 & 0 & 0 & 0 & 1 & 0.2 \\
\hline MCRKG & $1,3,26,3 \mathrm{ka}, 11,30,10,14 \mathrm{a}, 18,28$ & 1 & 1.1 & 0 & 0 & 0 & 0 & 1 & 1.4 & 0 & 0 & 0 & 0 & 2 & 0.5 \\
\hline MCTNB & $1,3,26,3 \mathrm{ka}, 11,17,30, \mathrm{~B}, 14 \mathrm{a}$ & 10 & 10.8 & 3 & 14.3 & 6 & 15 & 0 & 0 & 1 & 1.3 & 0 & 0 & 20 & 4.5 \\
\hline MCTSB & $1,3,26,3 \mathrm{ka}, 11,17,30, \mathrm{~B}, 10,14 \mathrm{a}$ & 2 & 2.2 & 0 & 0 & 0 & 0 & 0 & 0 & 0 & 0 & 0 & 0 & 2 & 0.5 \\
\hline MDDSB & $1,3,24,17, \mathrm{~B}, 10,14 \mathrm{a}$ & 0 & 0 & 0 & 0 & 0 & 0 & 2 & 2.8 & 0 & 0 & 0 & 0 & 2 & 0.5 \\
\hline MDPSB & $1,3,24,3 \mathrm{ka}, 17,30, \mathrm{~B}, 10,14 \mathrm{a}$ & 1 & 1.1 & 0 & 0 & 0 & 0 & 0 & 0 & 3 & 3.8 & 2 & 1.5 & 6 & 1.4 \\
\hline MDTSB & $1,3,24,3 \mathrm{ka}, 11,17,30, \mathrm{~B}, 10,14 \mathrm{a}$ & 0 & 0 & 0 & 0 & 0 & 0 & 1 & 1.4 & 0 & 0 & 0 & 0 & 1 & 0.2 \\
\hline MFDSB & $1,3,24,26,17, \mathrm{~B}, 10,14 \mathrm{a}$ & 2 & 2.2 & 0 & 0 & 0 & 0 & 10 & 13.9 & 3 & 3.8 & 6 & 4.4 & 21 & 4.8 \\
\hline MFGJG & $1,3,24,26,11,10,14 \mathrm{a}, 28$ & 2 & 2.2 & 0 & 0 & 0 & 0 & 0 & 0 & 0 & 0 & 0 & 0 & 2 & 0.5 \\
\hline MFNJG & $1,3,24,26,3 \mathrm{ka}, 17,10,14 \mathrm{a}, 28$ & 0 & 0 & 0 & 0 & 0 & 0 & 0 & 0 & 0 & 0 & 1 & 0.7 & 1 & 0.2 \\
\hline MFNSB & $1,3,24,26,3 \mathrm{ka}, 17, \mathrm{~B}, 10,14 \mathrm{a}$ & 4 & 4.3 & 0 & 0 & 0 & 0 & 3 & 4.2 & 0 & 0 & 7 & 5.1 & 14 & 3.2 \\
\hline MFPSB & $1,3,24,26,3 \mathrm{ka}, 17,30, \mathrm{~B}, 10,14 \mathrm{a}$ & 5 & 5.4 & 0 & 0 & 0 & 0 & 0 & 0 & 1 & 1.3 & 4 & 2.9 & 10 & 2.3 \\
\hline MFRJG & $1,3,24,26,3 \mathrm{ka}, 11,30,10,14 \mathrm{a}, 28$ & 5 & 5.4 & 0 & 0 & 0 & 0 & 0 & 0 & 0 & 0 & 0 & 0 & 5 & 1.1 \\
\hline MFTSB & $1,3,24,26,3 \mathrm{ka}, 11,17,30, \mathrm{~B}, 10,14 \mathrm{a}$ & 0 & 0 & 0 & 0 & 0 & 0 & 2 & 2.8 & 0 & 0 & 1 & 0.7 & 3 & 0.7 \\
\hline MGDSD & $1,3,16,17, \mathrm{~B}, 10,14 \mathrm{a}, 39 / 41$ & 0 & 0 & 0 & 0 & 0 & 0 & 1 & 1.4 & 0 & 0 & 0 & 0 & 1 & 0.2 \\
\hline MKDSB & $1,3,16,24,26,17, \mathrm{~B}, 10,14 \mathrm{a}$ & 1 & 1.1 & 0 & 0 & 0 & 0 & 1 & 1.4 & 0 & 0 & 0 & 0 & 2 & 0.5 \\
\hline MLDSD & $1,3,9,17, \mathrm{~B}, 10,14 \mathrm{a}, 39 / 41$ & 10 & 10.8 & 3 & 14.3 & 0 & 0 & 9 & 12.5 & 2 & 2.6 & 10 & 7.4 & 34 & 7.7 \\
\hline MLNSD & $1,3,9,3 \mathrm{ka}, 17, \mathrm{~B}, 10,14 \mathrm{a}, 39 / 41$ & 1 & 1.1 & 0 & 0 & 0 & 0 & 0 & 0 & 0 & 0 & 0 & 0 & 1 & 0.2 \\
\hline MMDSD & $1,3,9,26,17, \mathrm{~B}, 10,14 \mathrm{a}, 39 / 41$ & 1 & 1.1 & 0 & 0 & 0 & 0 & 0 & 0 & 0 & 0 & 0 & 0 & 1 & 0.2 \\
\hline MMNSD & $1,3,9,26,3 \mathrm{ka}, 17, \mathrm{~B}, 10,14 \mathrm{a}, 39 / 41$ & 0 & 0 & 0 & 0 & 0 & 0 & 0 & 0 & 0 & 0 & 1 & 0.7 & 1 & 0.2 \\
\hline MMPSD & $1,3,9,26,3 \mathrm{ka}, 17,30, \mathrm{~B}, 10,14 \mathrm{a}, 39 / 41$ & 0 & 0 & 0 & 0 & 0 & 0 & 0 & 0 & 0 & 0 & 1 & 0.7 & 1 & 0.2 \\
\hline NBBRG & $1,2 \mathrm{c}, \mathrm{B}, 10,18,28$ & 3 & 3.2 & 1 & 4.8 & 0 & 0 & 2 & 2.8 & 1 & 1.3 & 2 & 1.5 & 9 & 2 \\
\hline NBBSG & $1,2 \mathrm{c}, \mathrm{B}, 10,14 \mathrm{a}, 28$ & 0 & 0 & 2 & 9.5 & 0 & 0 & 0 & 0 & 0 & 0 & 0 & 0 & 2 & 0.5 \\
\hline \multirow[t]{2}{*}{ NBBTG } & $1,2 \mathrm{c}, \mathrm{B}, 10,14 \mathrm{a}, 18,28$ & 0 & 0 & 3 & 14.3 & 0 & 0 & 0 & 0 & 0 & 0 & 0 & 0 & 3 & 0.7 \\
\hline & & & & & & & & & & & & \multicolumn{4}{|c|}{ (continued on next page) } \\
\hline
\end{tabular}

${ }^{a}$ Lines tested were Thatcher lines with genes $L r 1, L r 2 a, L r 2 c, L r 3 a, L r 9, L r 16, L r 24, L r 26, L r 3 k a, L r 11, L r 17, L r 30, L r B, L r 10, L r 14 a, L r 18, L r 21, L r 28$, and a winter wheat line with gene $L r 39 / 41$.

${ }^{\mathrm{b}}$ States of AR, DE, GA, LA, MD, MS, NC, VA.

c State of NY.

${ }^{\mathrm{d}}$ States of IL, IN, eastern MO, WI.

e States of OK, TX.

${ }^{\mathrm{f}}$ States of IA, KS, western MO

g States of MN, ND, SD. 
wheat cultivar Little Club, that had been treated with a maleic hydrazide solution of approximately $0.01 \mathrm{~g}$ (dissolved in $30 \mathrm{ml} \mathrm{H}_{2} \mathrm{O}$ ) per pot to enhance spore production. Each pot of 10 to 20 seedlings was sprayed with $0.25 \mathrm{ml}$ of a suspension of spores in Soltrol 170 (Phillips Petroleum, Bartlesville, OK) mineral oil. After drying for $1 \mathrm{~h}$, inoculated plants were placed in a dew chamber overnight at $18^{\circ} \mathrm{C}$. The plants were then placed in individual Plexiglas isolation chambers in a greenhouse where temperatures varied between 18 and $28^{\circ} \mathrm{C}$ daily under at least $8 \mathrm{~h}$ of natural light, with supplemental greenhouse lighting. After 12 to 15 days, three seedlings were saved per collection, each with the primary leaf trimmed to isolate a single uredinium. Six to 9 days later, a cyclone spore collector was used to collect urediniospores separately from two to three single uredinia per collection. The isolates were increased through one uredinial generation on seedlings of Little Club before inoculating differential lines. Two to three milligrams of urediniospores of the single-uredinial isolates were mixed with $0.25 \mathrm{ml}$ of oil and directly inoculated by atomization onto 7- to 8-day-old plants of the differential host series (five to seven plants per line) of near-isogenic lines of Thatcher wheat with single resistance genes
Lr1, Lr2a, Lr2c, Lr3, Lr3ka, Lr9, Lr10, Lr11, Lr14a, Lr16, Lr17, $\operatorname{Lr} 18, \operatorname{Lr} 21, \operatorname{Lr} 24, \operatorname{Lr} 26, \operatorname{Lr} 28, \operatorname{Lr} 30$, and $\operatorname{LrB}$, and a winter wheat line with the gene $\operatorname{Lr} 39$ that had been previously designated as Lr41. A winter wheat line with $L r 42$ was used in the surveys from 2004 to 2007; however, this line was dropped since it was later determined to also have $\operatorname{Lr} 24$, which greatly limited the effectiveness of this line as a differential.

Sets of differential lines were grown in the greenhouse and evaluated for rust infection type from April to June and from September through the end of January. Natural daylight was supplemented with high-pressure sodium lamps from 0800 to $2400 \mathrm{~h}$. After 10 to 12 days, infection types (IT) were recorded as either high (IT 3 to 4) or low (IT 0 to $2^{+}$) as previously described (12). A five-letter code based on the original code proposed for $P$. triticina (11) describes the low or high infection types of each isolate to the 19 differential lines. Each letter corresponds to the infection types of four differentials. The Thatcher lines with genes $\operatorname{Lr} 1, L r 2 a, L r 2 c$, and $L r 3$ were the four lines in the first set of differentials; lines with genes $\operatorname{Lr} 9, \operatorname{Lr} 16, \operatorname{Lr} 24$, and $\operatorname{Lr} 26$ were the second set of differentials; lines with genes $L r 3 k a, L r 11, L r 17$, and $\operatorname{Lr} 30$ were the

Table 1. (continued from preceding page)

\begin{tabular}{|c|c|c|c|c|c|c|c|c|c|c|c|c|c|c|c|}
\hline \multirow[b]{2}{*}{ Phenotype } & \multirow[b]{2}{*}{ Virulence } & \multicolumn{2}{|c|}{ Area $1^{\text {b }}$} & \multicolumn{2}{|c|}{ Area $2^{c}$} & \multicolumn{2}{|c|}{ Area $3^{\text {d }}$} & \multicolumn{2}{|c|}{ Area $4^{e}$} & \multicolumn{2}{|c|}{ Area $5^{f}$} & \multicolumn{2}{|c|}{ Area $6^{g}$} & \multicolumn{2}{|c|}{ Total } \\
\hline & & $\#$ & $\%$ & $\#$ & $\%$ & $\#$ & $\%$ & $\#$ & $\%$ & $\#$ & $\%$ & $\#$ & $\%$ & $\#$ & $\%$ \\
\hline SBBGG & $1,2 \mathrm{a}, 2 \mathrm{c}, 10,28$ & 0 & 0 & 0 & 0 & 0 & 0 & 0 & 0 & 1 & 1.3 & 0 & 0 & 1 & 0.2 \\
\hline TBBBG & $1,2 \mathrm{a}, 2 \mathrm{c}, 3,28$ & 0 & 0 & 0 & 0 & 0 & 0 & 1 & 1.4 & 0 & 0 & 0 & 0 & 1 & 0.2 \\
\hline TBBDJ & $1,2 \mathrm{a}, 2 \mathrm{c}, 3,14 \mathrm{a}, 28,39 / 41$ & 0 & 0 & 0 & 0 & 1 & 2.5 & 0 & 0 & 0 & 0 & 0 & 0 & 1 & 0.2 \\
\hline TBBGD & $1,2 \mathrm{a}, 2 \mathrm{c}, 3,10,39 / 41$ & 0 & 0 & 0 & 0 & 0 & 0 & 1 & 1.4 & 0 & 0 & 0 & 0 & 1 & 0.2 \\
\hline TBBGG & $1,2 \mathrm{a}, 2 \mathrm{c}, 3,10,28$ & 0 & 0 & 0 & 0 & 0 & 0 & 0 & 0 & 3 & 3.8 & 1 & 0.7 & 4 & 0.9 \\
\hline TBBGJ & $1,2 \mathrm{a}, 2 \mathrm{c}, 3,10,28,39 / 41$ & 0 & 0 & 0 & 0 & 3 & 7.5 & 13 & 18.1 & 16 & 20.5 & 20 & 14.7 & 52 & 11.8 \\
\hline TBBJG & $1,2 \mathrm{a}, 2 \mathrm{c}, 3,10,14 \mathrm{a}, 28$ & 0 & 0 & 0 & 0 & 0 & 0 & 0 & 0 & 1 & 1.3 & 0 & 0 & 1 & 0.2 \\
\hline TBBQJ & $1,2 \mathrm{a}, 2 \mathrm{c}, 3, \mathrm{~B}, 10,28,39 / 41$ & 0 & 0 & 0 & 0 & 0 & 0 & 0 & 0 & 1 & 1.3 & 0 & 0 & 1 & 0.2 \\
\hline TBGJG & $1,2 \mathrm{a}, 2 \mathrm{c}, 3,11,10,14 \mathrm{a}, 28$ & 0 & 0 & 0 & 0 & 0 & 0 & 0 & 0 & 1 & 1.3 & 0 & 0 & 1 & 0.2 \\
\hline TBHKG & $1,2 \mathrm{a}, 2 \mathrm{c}, 3,11,30,10,14 \mathrm{a}, 18,28$ & 0 & 0 & 0 & 0 & 0 & 0 & 0 & 0 & 1 & 1.3 & 0 & 0 & 1 & 0.2 \\
\hline TBJJG & $1,2 \mathrm{a}, 2 \mathrm{c}, 3,11,17,10,14 \mathrm{a}, 28$ & 1 & 1.1 & 0 & 0 & 0 & 0 & 0 & 0 & 0 & 0 & 1 & 0.7 & 2 & 0.5 \\
\hline TBMKG & $1,2 \mathrm{a}, 2 \mathrm{c}, 3,3 \mathrm{ka}, 30,10,14 \mathrm{a}, 18,28$ & 1 & 1.1 & 0 & 0 & 0 & 0 & 0 & 0 & 0 & 0 & 0 & 0 & 1 & 0.2 \\
\hline TBPSB & $1,2 \mathrm{a}, 2 \mathrm{c}, 3,3 \mathrm{ka}, 17,30, \mathrm{~B}, 10,14 \mathrm{a}$ & 0 & 0 & 0 & 0 & 0 & 0 & 0 & 0 & 1 & 1.3 & 0 & 0 & 1 & 0.2 \\
\hline TBRKG & $1,2 \mathrm{a}, 2 \mathrm{c}, 3,3 \mathrm{ka}, 11,30,10,14 \mathrm{a}, 18,28$ & 2 & 2.2 & 1 & 4.8 & 6 & 15 & 0 & 0 & 1 & 1.3 & 0 & 0 & 10 & 2.3 \\
\hline TCBGJ & $1,2 \mathrm{a}, 2 \mathrm{c}, 3,26,10,28,39 / 41$ & 0 & 0 & 0 & 0 & 0 & 0 & 1 & 1.4 & 0 & 0 & 2 & 1.5 & 3 & 0.7 \\
\hline TCBJG & $1,2 \mathrm{a}, 2 \mathrm{c}, 3,26,10,14 \mathrm{a}, 28$ & 5 & 5.4 & 0 & 0 & 0 & 0 & 0 & 0 & 0 & 0 & 0 & 0 & 5 & 1.1 \\
\hline TCBSG & $1,2 \mathrm{a}, 2 \mathrm{c}, 3,26, \mathrm{~B}, 10,14 \mathrm{a}, 28$ & 1 & 1.1 & 0 & 0 & 0 & 0 & 0 & 0 & 0 & 0 & 0 & 0 & 1 & 0.2 \\
\hline TCGJG & $1,2 \mathrm{a}, 2 \mathrm{c}, 3,26,11,10,14 \mathrm{a}, 28$ & 0 & 0 & 1 & 4.8 & 0 & 0 & 0 & 0 & 0 & 0 & 0 & 0 & 1 & 0.2 \\
\hline TCJSB & $1,2 \mathrm{a}, 2 \mathrm{c}, 3,26,11,17, \mathrm{~B}, 10,14 \mathrm{a}$ & 2 & 2.2 & 0 & 0 & 0 & 0 & 0 & 0 & 0 & 0 & 1 & 0.7 & 3 & 0.7 \\
\hline TCJSG & $1,2 \mathrm{a}, 2 \mathrm{c}, 3,26,11,17, \mathrm{~B}, 10,14 \mathrm{a}, 28$ & 2 & 2.2 & 0 & 0 & 0 & 0 & 0 & 0 & 0 & 0 & 0 & 0 & 2 & 0.5 \\
\hline TCRKG & $1,2 \mathrm{a}, 2 \mathrm{c}, 3,26,3 \mathrm{ka}, 11,30,10,14 \mathrm{a}, 18,28$ & 10 & 10.8 & 1 & 4.8 & 8 & 20 & 1 & 1.4 & 5 & 6.4 & 4 & 2.9 & 29 & 6.6 \\
\hline TCTBG & $1,2 \mathrm{a}, 2 \mathrm{c}, 3,26,3 \mathrm{ka}, 11,17,30,28$ & 1 & 1.1 & 0 & 0 & 0 & 0 & 0 & 0 & 0 & 0 & 0 & 0 & 1 & 0.2 \\
\hline TCTSB & $1,2 \mathrm{a}, 2 \mathrm{c}, 3,26,3 \mathrm{ka}, 11,17,30, \mathrm{~B}, 10,14 \mathrm{a}$ & 0 & 0 & 0 & 0 & 3 & 7.5 & 0 & 0 & 0 & 0 & 0 & 0 & 3 & 0.7 \\
\hline TDBGG & $1,2 \mathrm{a}, 2 \mathrm{c}, 3,24,10,28$ & 0 & 0 & 0 & 0 & 0 & 0 & 1 & 1.4 & 5 & 6.4 & 13 & 9.6 & 19 & 4.3 \\
\hline TDBGJ & $1,2 \mathrm{a}, 2 \mathrm{c}, 3,24,10,28,39 / 41$ & 0 & 0 & 0 & 0 & 0 & 0 & 1 & 1.4 & 0 & 0 & 0 & 0 & 1 & 0.2 \\
\hline TDBGQ & $1,2 \mathrm{a}, 2 \mathrm{c}, 3,24,10,21,28$ & 0 & 0 & 0 & 0 & 0 & 0 & 0 & 0 & 0 & 0 & 15 & 11 & 15 & 3.4 \\
\hline TDBJG & $1,2 \mathrm{a}, 2 \mathrm{c}, 3,24,10,14 \mathrm{a}, 28$ & 1 & 1.1 & 0 & 0 & 2 & 5 & 0 & 0 & 3 & 3.8 & 4 & 2.9 & 10 & 2.3 \\
\hline TDBJQ & $1,2 \mathrm{a}, 2 \mathrm{c}, 3,24,10,14 \mathrm{a}, 21,28$ & 1 & 1.1 & 0 & 0 & 0 & 0 & 3 & 4.2 & 0 & 0 & 1 & 0.7 & 5 & 1.1 \\
\hline TDDJG & $1,2 \mathrm{a}, 2 \mathrm{c}, 3,24,17,10,14 \mathrm{a}, 28$ & 0 & 0 & 0 & 0 & 0 & 0 & 0 & 0 & 0 & 0 & 1 & 0.7 & 1 & 0.2 \\
\hline TFBGG & $1,2 \mathrm{a}, 2 \mathrm{c}, 3,24,26,10,28$ & 0 & 0 & 0 & 0 & 0 & 0 & 0 & 0 & 0 & 0 & 2 & 1.5 & 2 & 0.5 \\
\hline TFBGJ & $1,2 \mathrm{a}, 2 \mathrm{c}, 3,24,26,10,28,39 / 41$ & 0 & 0 & 0 & 0 & 0 & 0 & 0 & 0 & 0 & 0 & 1 & 0.7 & 1 & 0.2 \\
\hline TFBGQ & $1,2 \mathrm{a}, 2 \mathrm{c}, 3,24,26,10,21,28$ & 0 & 0 & 0 & 0 & 0 & 0 & 0 & 0 & 1 & 1.3 & 5 & 3.7 & 6 & 1.4 \\
\hline TFBJG & $1,2 \mathrm{a}, 2 \mathrm{c}, 3,24,26,10,14 \mathrm{a}, 28$ & 1 & 1.1 & 0 & 0 & 0 & 0 & 0 & 0 & 0 & 0 & 0 & 0 & 1 & 0.2 \\
\hline TFBJQ & $1,2 \mathrm{a}, 2 \mathrm{c}, 3,24,26,10,14 \mathrm{a}, 21,28$ & 0 & 0 & 0 & 0 & 0 & 0 & 0 & 0 & 0 & 0 & 1 & 0.7 & 1 & 0.2 \\
\hline TFBKG & $1,2 \mathrm{a}, 2 \mathrm{c}, 3,24,26,10,14 \mathrm{a}, 18,28$ & 0 & 0 & 0 & 0 & 0 & 0 & 0 & 0 & 0 & 0 & 1 & 0.7 & 1 & 0.2 \\
\hline TFJGG & $1,2 \mathrm{a}, 2 \mathrm{c}, 3,24,26,11,17,10,28$ & 0 & 0 & 0 & 0 & 0 & 0 & 0 & 0 & 0 & 0 & 1 & 0.7 & 1 & 0.2 \\
\hline TFLJJ & $1,2 \mathrm{a}, 2 \mathrm{c}, 3,24,26,3 \mathrm{ka}, 10,14 \mathrm{a}, 28,39 / 41$ & 0 & 0 & 0 & 0 & 0 & 0 & 0 & 0 & 0 & 0 & 1 & 0.7 & 1 & 0.2 \\
\hline TFPSB & $1,2 \mathrm{a}, 2 \mathrm{c}, 3,24,26,3 \mathrm{ka}, 17,30, \mathrm{~B}, 10,14 \mathrm{a}$ & 2 & 2.2 & 0 & 0 & 0 & 0 & 0 & 0 & 0 & 0 & 0 & 0 & 2 & 0.5 \\
\hline TFRJG & $1,2 \mathrm{a}, 2 \mathrm{c}, 3,24,26,3 \mathrm{ka}, 11,30,10,14 \mathrm{a}, 28$ & 1 & 1.1 & 0 & 0 & 0 & 0 & 0 & 0 & 0 & 0 & 0 & 0 & 1 & 0.2 \\
\hline TGBJG & $1,2 \mathrm{a}, 2 \mathrm{c}, 3,16,10,14 \mathrm{a}, 28$ & 0 & 0 & 0 & 0 & 0 & 0 & 0 & 0 & 1 & 1.3 & 0 & 0 & 1 & 0.2 \\
\hline THBJG & $1,2 \mathrm{a}, 2 \mathrm{c}, 3,16,26,10,14 \mathrm{a}, 28$ & 1 & 1.1 & 0 & 0 & 0 & 0 & 1 & 1.4 & 0 & 0 & 0 & 0 & 2 & 0.5 \\
\hline TJBGQ & $1,2 \mathrm{a}, 2 \mathrm{c}, 3,16,24,10,21,28$ & 0 & 0 & 0 & 0 & 0 & 0 & 0 & 0 & 0 & 0 & 2 & 1.5 & 2 & 0.5 \\
\hline TLBJJ & $1,2 \mathrm{a}, 2 \mathrm{c}, 3,9,10,14 \mathrm{a}, 28,39 / 41$ & 0 & 0 & 0 & 0 & 0 & 0 & 0 & 0 & 1 & 1.3 & 1 & 0.7 & 2 & 0.5 \\
\hline TNBGJ & $1,2 \mathrm{a}, 2 \mathrm{c}, 3,9,24,10,28,39 / 41$ & 0 & 0 & 0 & 0 & 0 & 0 & 9 & 12.5 & 12 & 15.4 & 6 & 4.4 & 27 & 6.1 \\
\hline TNBJJ & $1,2 \mathrm{a}, 2 \mathrm{c}, 3,9,24,10,14 \mathrm{a}, 28,39$ & 3 & 3.2 & 0 & 0 & 0 & 0 & 0 & 0 & 0 & 0 & 1 & 0.7 & 4 & 0.9 \\
\hline TNGFJ & $1,2 \mathrm{a}, 2 \mathrm{c}, 3,9,24,11,14 \mathrm{a}, 18,28,39 / 41$ & 0 & 0 & 0 & 0 & 0 & 0 & 1 & 1.4 & 0 & 0 & 0 & 0 & 1 & 0.2 \\
\hline TNRJJ & $1,2 \mathrm{a}, 2 \mathrm{c}, 3,9,24,3 \mathrm{ka}, 11,30,10,14 \mathrm{a}, 28,39 / 41$ & 3 & 3.2 & 0 & 0 & 0 & 0 & 3 & 4.2 & 0 & 0 & 0 & 0 & 6 & 1.4 \\
\hline TPBGJ & $1,2 \mathrm{a}, 2 \mathrm{c}, 3,9,24,26,10,28,39 / 41$ & 0 & 0 & 0 & 0 & 0 & 0 & 2 & 2.8 & 1 & 1.3 & 1 & 0.7 & 4 & 0.9 \\
\hline Total & & 93 & & 21 & & 40 & & 72 & & 78 & & 136 & & 440 & \\
\hline
\end{tabular}


third set of differentials; lines with genes $\operatorname{LrB}, \operatorname{Lr} 10, \operatorname{Lr} 14 a$, and $L r 18$ were the fourth set of differentials; and lines with genes $\operatorname{Lr} 21$, $L r 28$, and $L r 39 / 41$ were the fifth set of differentials. The fourth differential in the fifth set was not designated. Therefore, the fourth differential position was always designated as a low IT for coding phenotypes. Sets 1 to 3 are the same as described previously (11). The same first four sets of differentials have been used in P. triticina surveys in Canada (14). The fifth set of differentials was added for the first time in U.S. surveys in 2004, since Lr21 is present in spring wheat cultivars, $L r 39 / 41$ is present in winter wheat cultivars, and $L r 28$ differentiates $P$. triticina virulence phenotypes.

Phenotype and virulence frequencies were determined for collections from eight agroecological geographic areas as shown and described in Figure 1. Collections were not obtained from areas 7 and 8 in 2011. A modified version of Nei's genetic distance (15) between isolates in areas 1, 2, 3, 4, 5, and 6 was calculated with NTSYS-pc v2.1 (Exeter Software, Seatauket, NY) in which the frequency of isolates with virulence to a leaf rust resistance gene was used in place of allele frequency. The distance matrix of Nei's virulence distance between the areas was plotted by unweighted pair group method with arithmetic mean (UPGMA) clustering in NTSYS-pc v2.1.

The leaf rust resistance genes present in the current soft red winter wheat cultivars, hard red winter wheat cultivars, and hard red spring wheat cultivars were postulated based on infection types to different virulence phenotypes of $P$. triticina using previously cited methods $(8,16)$. The infection types of the cultivars to different $P$. triticina isolates and the postulated leaf rust resistance genotypes of the cultivars are available at the USDA-ARS Cereal Disease Laboratory website in the germplasm evaluation section (http:// www.ars.usda.gov/Main/docs.htm?docid=9987).

\section{Results}

Leaf rust occurrence and isolate collections. Leaf rust was found in south Texas and in Oklahoma in early March. Generally, leaf rust was widespread but at low severity levels in fields and plots throughout the southern and northern Great Plains region of the United States. Extreme drought conditions in the southern and central plains limited leaf rust development and reduced the amount of inoculum carried by the southerly winds to the northern plains region. Many fields in the southern and central Great Plains regions were sprayed with fungicide to reduce losses due to leaf rust and stripe rust; this also reduced the amount of leaf rust inoculum carried by the southerly winds into the northern states. The commonly grown hard red winter wheat cultivars such as Jackpot, Postrock, TAM 112, Armour, and Overley with Lr39/41; Jagalene (Lr24); Fuller ( $\operatorname{rr17}, L r 39 / 41)$; and TAM 111 (Lr17) were susceptible to leaf with rust severities reaching 70 to $100 \%$ in fields and plots by mid-May in central Oklahoma.

In late May, leaf rust was observed in winter wheat plots in southern Minnesota. Leaf rust increased to high severity levels in winter wheat plots in southern Minnesota by late June. In mid-July, low levels of leaf rust infections were found in spring wheat plots in central and northwestern Minnesota. Plots of spring wheat in north-central and northeast North Dakota had moderate severity levels of leaf rust in the last week of July. The spring wheat cultivars Faller and Prosper with $L r 21$ had moderate rust severity in plots in North Dakota and Minnesota.

Leaf rust was found in plots of soft red winter wheat in Georgia in early March and in Louisiana and Mississippi in late March, which was somewhat later than usually observed. Leaf rust development and spread was limited in the southeastern states in 2011 due to the late initial onset of rust and also due to the use of fungicides in this region. Throughout the southeastern states, the wheat crop matured before leaf rust reached damaging levels. In Wisconsin, leaf rust was found in fields of soft red winter wheat in early June and was present in moderate to high severity in plots in northeastern Wisconsin in the first week of July. Leaf rust was present in low incidence and severity in fields of soft white winter wheat in New York State by the end of June. Individual fields had high levels of leaf rust that likely resulted from overwintering local infections. A complete summary of the leaf rust incidence in 2011 in the United States can be found at the USDA-ARS Cereal Disease Laboratory website (http://www.ars.usda.gov/main/site_main.htm? modecode $=36400500)$.

Distribution of virulence phenotypes. In 2011, 87 virulence phenotypes of wheat leaf rust were identified in the United States from 440 single-uredinial isolates that were tested on the Thatcher lines (Table 1). Phenotypes TBBGJ (11.8\%), MLDSD (7.7\%), TCRKG (6.6\%), TNBGJ (6.1\%), and MFDSB (4.8\%) were the five

Table 2. Number and frequency (\%) of isolates of Puccinia triticina in the United States in 2011 virulent to 19 lines of wheat with single resistance genes for leaf rust resistance

\begin{tabular}{|c|c|c|c|c|c|c|c|c|c|c|c|c|c|c|}
\hline \multirow{2}{*}{$\begin{array}{l}\text { Resistance } \\
\text { gene }\end{array}$} & \multicolumn{2}{|c|}{ Area $1^{a}$} & \multicolumn{2}{|c|}{ Area $2^{b}$} & \multicolumn{2}{|c|}{ Area $3^{c}$} & \multicolumn{2}{|c|}{ Area $4^{d}$} & \multicolumn{2}{|c|}{ Area $5^{\mathrm{e}}$} & \multicolumn{2}{|c|}{ Area $6^{f}$} & \multicolumn{2}{|c|}{ Total } \\
\hline & $\#$ & $\%$ & \# & $\%$ & $\#$ & $\%$ & $\#$ & $\%$ & $\#$ & $\%$ & \# & $\%$ & \# & $\%$ \\
\hline Lr1 & 92 & 98.9 & 21 & 100 & 40 & 100 & 72 & 100 & 75 & 96.2 & 134 & 98.5 & 434 & 98.6 \\
\hline Lr2a & 38 & 40.9 & 3 & 14.3 & 23 & 57.5 & 38 & 52.8 & 55 & 70.5 & 86 & 63.2 & 243 & 55.2 \\
\hline Lr2c & 41 & 44.1 & 9 & 42.9 & 23 & 57.5 & 40 & 55.6 & 56 & 71.8 & 88 & 64.7 & 257 & 58.4 \\
\hline Lr3 & 89 & 95.7 & 15 & 71.4 & 40 & 100 & 70 & 97.2 & 73 & 93.6 & 132 & 97.1 & 419 & 95.2 \\
\hline Lr9 & 18 & 19.4 & 3 & 14.3 & 0 & 0 & 24 & 33.3 & 16 & 20.5 & 21 & 15.4 & 82 & 18.6 \\
\hline Lr16 & 2 & 2.2 & 0 & 0 & 0 & 0 & 3 & 4.2 & 1 & 1.3 & 2 & 1.5 & 8 & 1.8 \\
\hline Lr24 & 32 & 34.4 & 0 & 0 & 2 & 5 & 39 & 54.2 & 29 & 37.2 & 77 & 56.6 & 179 & 40.7 \\
\hline Lr26 & 59 & 63.4 & 10 & 47.6 & 21 & 52.5 & 23 & 31.9 & 15 & 19.2 & 45 & 33.1 & 173 & 39.3 \\
\hline Lr3ka & 54 & 58.1 & 8 & 38.1 & 28 & 70 & 11 & 15.3 & 16 & 20.5 & 30 & 22.1 & 147 & 33.4 \\
\hline Lr11 & 47 & 50.5 & 11 & 52.4 & 29 & 72.5 & 9 & 12.5 & 10 & 12.8 & 13 & 9.6 & 119 & 27 \\
\hline Lr17 & 51 & 54.8 & 7 & 33.3 & 19 & 47.5 & 31 & 43.1 & 20 & 25.6 & 49 & 36 & 177 & 40.2 \\
\hline Lr30 & 49 & 52.7 & 7 & 33.3 & 28 & 70 & 8 & 11.1 & 17 & 21.8 & 20 & 14.7 & 129 & 29.3 \\
\hline LrB & 53 & 57 & 14 & 66.7 & 19 & 47.5 & 33 & 45.8 & 21 & 26.9 & 47 & 34.6 & 187 & 42.5 \\
\hline Lr10 & 76 & 81.7 & 17 & 81 & 28 & 70 & 70 & 97.2 & 74 & 94.9 & 129 & 94.9 & 394 & 89.5 \\
\hline Lr14a & 89 & 95.7 & 18 & 85.7 & 37 & 92.5 & 41 & 56.9 & 37 & 47.4 & 65 & 47.8 & 287 & 65.2 \\
\hline Lr18 & 17 & 18.3 & 7 & 33.3 & 14 & 35 & 5 & 6.9 & 8 & 10.3 & 8 & 5.9 & 59 & 13.4 \\
\hline Lr21 & 1 & 1.1 & 0 & 0 & 0 & 0 & 3 & 4.2 & 1 & 1.3 & 24 & 17.6 & 29 & 6.6 \\
\hline Lr28 & 46 & 49.5 & 14 & 66.7 & 21 & 52.5 & 40 & 55.6 & 59 & 75.6 & 91 & 66.9 & 271 & 61.6 \\
\hline Lr39/41 & 19 & 20.4 & 3 & 14.3 & 5 & 12.5 & 43 & 59.7 & 38 & 48.7 & 47 & 34.6 & 155 & 35.2 \\
\hline Total & 93 & & 21 & & 40 & & 72 & & 78 & & 136 & & 440 & \\
\hline
\end{tabular}

a States of AR, DE, GA, LA, MD, MS, NC, VA.

b States of NY.

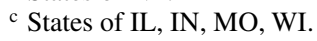

d States of OK, TX.

e States of IA, KS, MO.

${ }^{\mathrm{f}}$ States of MN, ND, SD. 
most frequent phenotypes across the United States. TCRKG was found in areas 1 through 6; TBBGJ was found in areas 3, 4, 5, and 6; MLDSD was found in all areas except area 3; TNBGJ was found in areas 4, 5, and 6; and MFDSB was found in areas 1, 4, 5, and 6. In the southeastern states (area 1), 34 virulence phenotypes were found among the 93 isolates that were tested (Table 1). Phenotypes MCTNB (10.8\%) MLDSD (10.8\%), and TCRKG (10.8\%) were the three most common phenotypes in this area. In the northeastern states (area 2), 12 virulence phenotypes were identified among the 21 isolates that were tested. Phenotypes MCGJG (14.3\%), MCTNB (14.3\%), MLDSD (14.3\%), and NBBTG (14.3\%) were the four most common phenotypes in this area. In the Ohio Valley states (area 3), 13 virulence phenotypes were described among the 40 isolates that were tested. Phenotypes TCRKG (20\%), TBRKG $(15 \%)$, and MBTNB (10\%) were the three most common phenotypes in this area. In Texas and Oklahoma (area 4), 25 virulence phenotypes were described among the 72 isolates that were tested. Phenotypes TBBGJ (18.1\%), MFDSB (13.9\%), MLDSD (12.5\%), and TNBGJ (12.5\%) were the four most common phenotypes in this area. In Kansas and Nebraska (area 5), 29 virulence phenotypes were described among the 78 isolates that were tested. Phenotypes TBBGJ (20.5\%), TNBGJ (15.4\%), TCRKG $(6.4 \%)$, and TDBGG $(6.4 \%)$ were the four most common phenotypes in this area. In Minnesota, North Dakota, and South Dakota (area 6), 41 virulence phenotypes were described among the 136 isolates that were tested. Phenotypes TBBGJ (14.7\%), TDBGQ (11\%), and TDBGG (9.6\%) were the three most common phenotypes in this area.

Virulence frequencies. Frequencies of virulence to the $L r$ genes differed among the regional populations of $P$. triticina in the United States and are listed in Table 2. The average of Nei's distance for virulence between the isolates in areas 5 and 6 with area 4 was 0.025 (Fig. 2). The average distance between isolates in areas 1,2 , and 3 was 0.0475 . The distance between isolates in areas 1,2 , and 3 with isolates in areas 4,5 , and 6 was 0.13 .

In area 1 (Fig. 3A), the frequency of isolates with virulence to $L r 24, L r 26$, and Lrl1 increased from 2010, and frequency of isolates with virulence to $\operatorname{Lr} 9$ and $\operatorname{Lr} 18$ declined. In area 4 (Fig. 3B), the frequency of isolates with virulence to $L r 24$ and $L r 26$ increased from 2010, and the frequency of isolates with virulence to $L r 9$ and Lr17 decreased. In area 6 (Fig. 3C), the frequency of isolates with virulence to $L r 2 a, L r 24$, and $L r 26$ increased from 2010, and the frequency of isolates with virulence to $\operatorname{Lrl6}$ and $\operatorname{Lr} 17$ declined.

\section{Discussion}

In 2011, as in previous years, the leaf rust resistance genes that are present in the hard red winter and soft red winter wheat cultivars selected the most prevalent virulence phenotypes of $P$. triticina. The most common phenotype, TBBGJ, and the fourth most common phenotype, TNBGJ, are virulent to $L r 39 / 41$ that is present in many hard red winter wheat cultivars such as Fuller, Postrock, TAM 112, Armour, and Overley that are grown in the southern Great Plains region. The second most common phenotype, MLDSD, is virulent to Lr39/41 and Lr17. The hard red winter wheat cultivars Fuller, Art, Jagger, and Santa Fe were postulated to have $L r 17$. The third most common phenotype, TCRKG, is virulent to genes $\operatorname{Lr11}, \operatorname{Lr} 18$, and $\operatorname{Lr} 26$. These genes were postulated to be present in soft red winter wheat cultivars such as Panola ( $L r 11)$, Coker 9553 ( $L r 11)$, Saluda (Lrl1), S550 (Lr26), USG3209 ( $L r 11$, Lr26), Sisson (Lr26), Jamestown (Lr11, Lr18), and Shirley (Lrl1, Lr18, Lr26) that are grown in the southern and eastern United States. In 2010, MLDSD, TDBJG, and TCRKG were the three most common phenotypes in the United States (9).

Phenotype TBBGJ was not detected in previous virulence surveys, yet it was nearly $12 \%$ of the U.S. P. triticina population in 2011. This phenotype was found throughout the Great Plains region due to selection by wheat cultivars with $L r 39 / 41$. TBBGJ is also notable because it has virulence to $L r 39 / 41$ but is avirulent to Lr9. In previous surveys, all isolates with virulence to $L r 39 / 41$ were also virulent to $\operatorname{Lr} 9$. Besides TBBGJ, 11 other phenotypes (MBDSD, MCDSD, MCPSD, MGDSD, TBBDJ, TBBGD, TBBQJ, TCBGJ, TDBGJ, TFBGJ, and TFLJJ) were also virulent to $L r 39 / 41$ but avirulent to $L r 9$. Ten phenotypes (MLDSD, MLNSD, MMDSD, MMNSD, MMPSD, TNBGJJ, TNBJJ, TNGFJ, TNRJJ, and TPBGJ) were virulent to both $\operatorname{Lr} 9$ and Lr39/41. A number of other new phenotypes were also detected. The most prominent of these were MBTNB found in areas 1, 2, 3, and 6; MCGJG found in area 2; MCTNB found in areas 1, 2, 3, and 5; MFDSB found in areas 1, 4, 5, and 6; TNBGJ found in areas 4, 5, and 6; and TDBGQ found in area 6.

There were strong geographical differences in distribution of the P. triticina phenotypes. Phenotypes MCTNB (virulent to $L r 11$, Lr26), TBRKG (virulent to $L r 11$ ), TCRKG (virulent to $L r 11, L r 18$, $L r 26$ ), and TCBJG (virulent to $L r 26$ ) were most common in areas 1, 2, and 3 where soft red winter wheat cultivars with $\operatorname{Lrl1} 1, \operatorname{Lr} 18$, and $L r 26$ are grown. Phenotypes MFDSB (virulent to $L r 24, L r 26$,

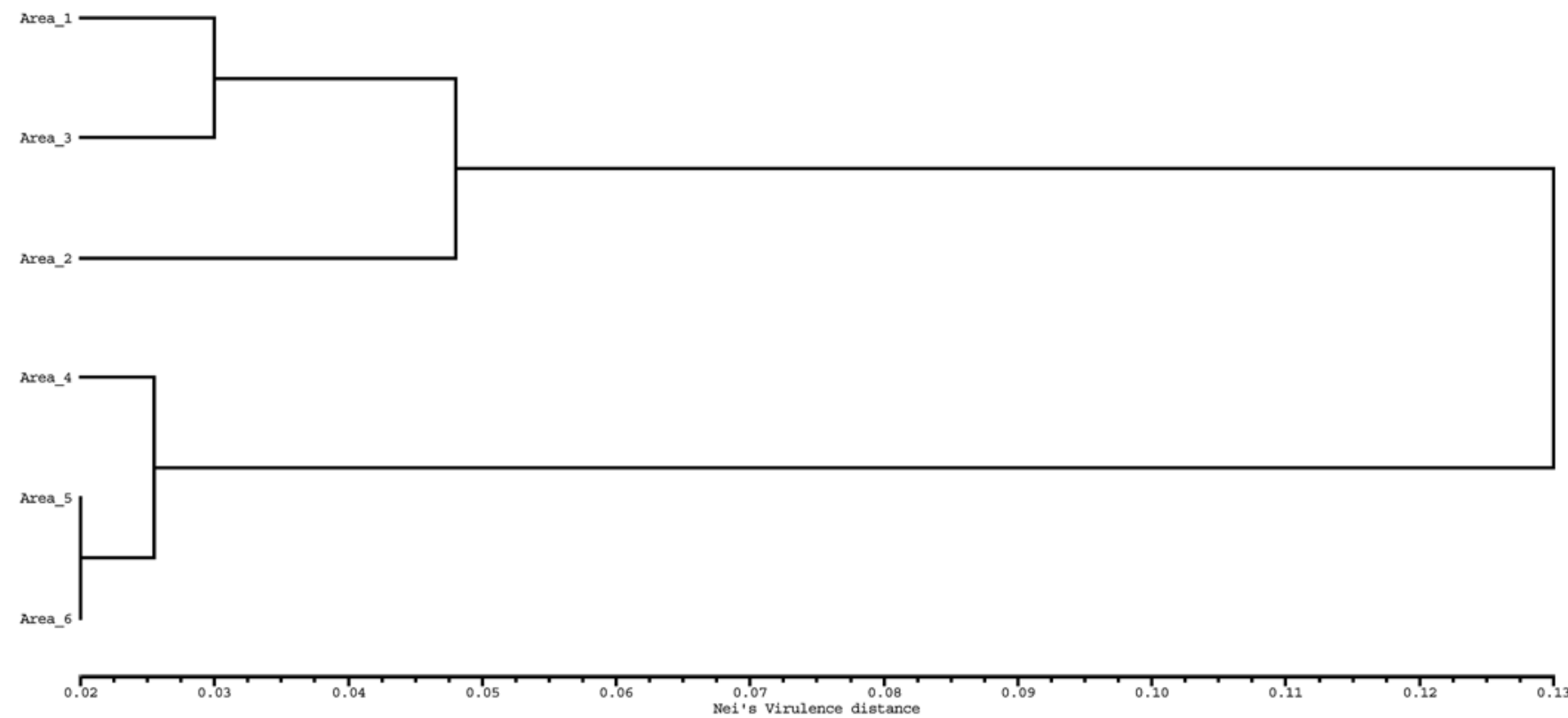

Fig. 2. Unweighted pair group method with arithmetic mean (UPGMA) dendrogram of Nei's genetic distance adapted for virulence of Puccinia triticina isolates in areas $1,2,3$, 4, 5, and 6 in the United States in 2011. 

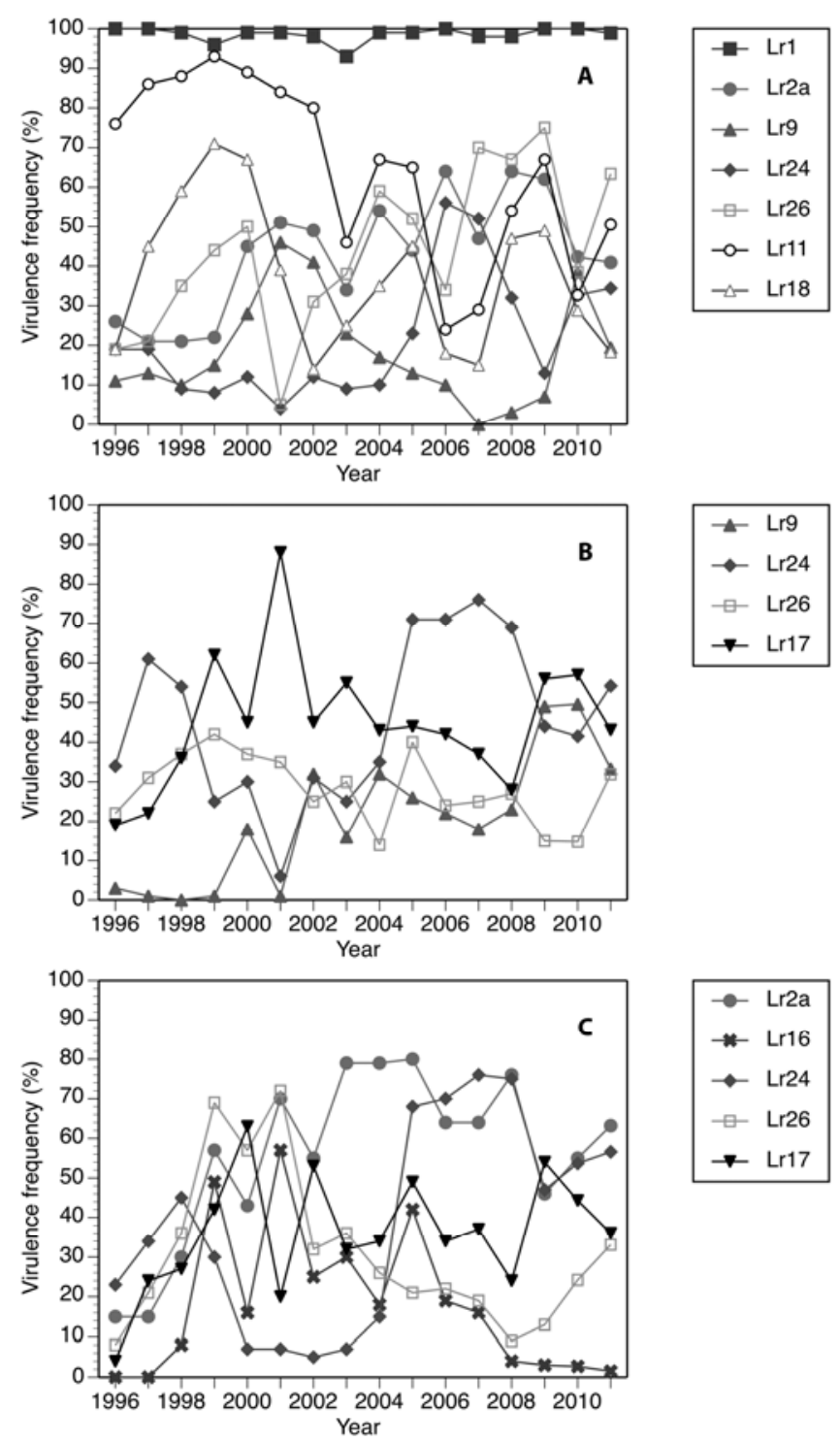

Fig. 3. Frequency (\%) of Puccinia triticina isolates with virulence to selected leaf rust resistance genes from 1996 to 2011 in the following areas of the United States: southeastern states (A, Area 1); southern Great Plains (B, Area 4); and northern Great Plains (C, Area 6).

Lr17), TBBGJ (virulent to $L r 39 / 41$ ), TDBGG (virulent to $L r 24$ ), and TNBGJ (virulent to $\operatorname{Lr} 9, \operatorname{Lr} 24, \operatorname{Lr} 39 / 41$ ) were most common in the Great Plains region of areas 4, 5, and 6. Hard red winter wheat cultivars with $\operatorname{Lr} 17, \operatorname{Lr} 24$, and $\operatorname{Lr} 39 / 41$ have selected for these phenotypes. This geographic difference is also seen in the Nei's virulence distance between isolates in the different areas. Isolates from the soft red winter wheat region of the southeastern states, Ohio Valley, and northeastern states were more similar for virulence compared to isolates from areas 4, 5, and 6 of the Great Plains where hard red winter wheat and hard red spring wheat cultivars are grown. This difference in virulence between the soft red wheat and hard red wheat regions was noted previously (10). The different $L r$ genes present in the soft red winter wheat cultivars and hard red wheat cultivars have contributed to maintaining different regional populations of $P$. triticina phenotypes in the United States.

In 2012, five phenotypes (TDBGQ, TDBJQ, TFBGQ, TFBJQ, and TJBGQ) had virulence to $L r 21$. These phenotypes were found mostly in area 6. Many spring wheats grown in Minnesota and North Dakota (Faller, Barlow, Glenn, Barlow, RB07, Prosper) have $L r 21$. These phenotypes are also virulent to $L r 2 a$ and $L r 24$ that are also present in some of the hard red spring wheat cultivars. Two phenotypes with virulence to $L r 21$ were first detected in the United States in 2010 (5). An increased number of phenotypes with Lr21 virulence will likely be detected in future years since cultivars with this gene are prevalent in the hard red spring wheat area.

The widespread use of wheat cultivars in the United States with genes that are effective in seedling plants and condition resistance to specific leaf rust phenotypes has led to the development of a $P$. triticina population that is highly diverse for virulence. Since populations of $P$. triticina in the United States are extremely large, it would be expected that recurrent mutations would generate new virulence phenotypes that will increase in response to leaf rust resistance genes in wheat cultivars. As new leaf rust resistant cultivars are released, it will be important to characterize the resistance in these cultivars by gene postulation, molecular markers, or genetic analysis in order to determine if leaf rust resistance genes in host cultivars have selected for new $P$. triticina virulence phenotypes.

\section{Literature Cited}

1. Appel, J. A., De Wolf, E., Bockus, W. W., and Bowden, R. L. 2007. Preliminary 2007 Kansas wheat disease loss estimates. Kansas Cooperative Plant Disease Survey Report, Kansas Department of Agriculture. Retrieved 16 February 2012 from http://www.ksda.gov/includes/document_center/ plant_protection/Plant_Disease_Reports/2007KSWheatDiseaseLossEstimat es.pdf

2. Chester, K. S. 1946. The Nature and Prevention of the Cereal Rusts as examplified in the Leaf Rust of Wheat. Waltham, MA.

3. Johnson, T. 1956. Physiologic races of leaf rust of wheat in Canada 1931 to 1955. Can. J. Agric. Sci. 36:323-332.

4. Johnston, C. O., Caldwell, R. M., Compton, L. E., and Browder, L. E. 1968 Physiologic races of Puccinia recondita f. sp. tritici in the United States from 1926 through 1960. U.S. Dep. Agric. Tech. Bull. 1393:1-18.

5. Kolmer, J., and Anderson, J. A. 2011. First detection in North America of virulence in wheat leaf rust (Puccinia triticina) to seedling plants of wheat with $L r 21$. Plant Dis. 95:1032.

6. Kolmer, J. A. 1999. Virulence dynamics, phenotypic diversity, and virulence complexity in two populations of Puccinia triticina in Canada from 19871997. Can. J. Bot. 77:333-338.

7. Kolmer, J. A. 2002. Virulence phenotypes of Puccinia triticina in the South Atlantic States in 1999. Plant Dis. 86:288-291.

8. Kolmer, J. A. 2003. Postulation of leaf rust resistance genes in selected soft red winter wheats. Crop Sci. 43:1266-1274.

9. Kolmer, J. A., Long, D. L., and Hughes, M. E. 2012. Physiologic specialization of Puccinia triticina on wheat in the United States in 2010. Plant Dis. 96:1216-1221.

10. Leonard, K. J., Roelfs, A. P., and Long, D. L. 1992. Diversity of virulence within and among populations of Puccinia recondita f. sp. tritici in different areas of the United States. Plant Dis. 76:500-504.

11. Long, D. L., and Kolmer, J. A. 1989. A North American system of nomenclature for Puccinia recondita f. sp. tritici. Phytopathology 79:525529.

12. Long, D. L., Schafer, J. F., and Roelfs, A. P. 1985. Specific virulence of Puccinia recondita f. sp. tritici in the United States from 1978 through 1983. Plant Dis. 69:343-347.

13. Mains, E. B., and Jackson, H. S. 1926. Physiologic specialization in the leaf rust of wheat, Puccinia triticina. Phyopthology 16:89-120.

14. McCallum, B. D., and Seto-Goh, P. 2006. Physiological specialization of Puccinia triticina, the casual agent of wheat leaf rust, in Canada in 2004. Can. J. Plant Pathol. 28:566-576.

15. Nei, M. 1972. Genetic distance between populations. Am. Naturalist 106:283-292.

16. Oelke, L. M., and Kolmer, J. A. 2004. Characterization of leaf rust resistance in hard red spring wheat cultivars. Plant Dis. 88:1127-1133.

17. Oelke, L. M., and Kolmer, J. A. 2005. Genetics of leaf rust resistance in the spring wheat cultivars Alsen and Norm. Phytopathology 95:773-778.

18. Roelfs, A. P. 1989. Epidemiology of the cereal rusts in North America. Can J. Plant Pathol. 11:86-90.

19. Roelfs, A. P., Singh, R. P., and Saari, E. E. 1992. Rust diseases of wheat: Concepts and methods of disease management. CIMMYT, Mexico, D.F. 